$11-1-2013$

\title{
On Comparison of Exponential and Hyperbolic Exponential Growth Models in Height/Diameter Increment of PINES (Pinus caribaea)
}

\section{S. O. Oyamakin}

University of Ibadan, Ibdan, Nigeria, fm_oyamakin@yahoo.com

\author{
A. U. Chukwu \\ University of Ibadan, Ibdan, Nigeria
}

T. A. Bamiduro

Redeemer's University, Ogun State, Nigeria

Follow this and additional works at: http://digitalcommons.wayne.edu/jmasm

Part of the Applied Statistics Commons, Social and Behavioral Sciences Commons, and the Statistical Theory Commons

\section{Recommended Citation}

Oyamakin, S. O.; Chukwu, A. U.; and Bamiduro, T. A. (2013) "On Comparison of Exponential and Hyperbolic Exponential Growth Models in Height/Diameter Increment of PINES (Pinus caribaea)," Journal of Modern Applied Statistical Methods: Vol. 12 : Iss. 2 , Article 24.

DOI: $10.22237 /$ jmasm/1383279780

Available at: http://digitalcommons.wayne.edu/jmasm/vol12/iss2/24

This Regular Article is brought to you for free and open access by the Open Access Journals at DigitalCommons@WayneState. It has been accepted for inclusion in Journal of Modern Applied Statistical Methods by an authorized editor of DigitalCommons@WayneState. 


\section{On Comparison of Exponential and Hyperbolic Exponential Growth Models in Height/Diameter Increment of PINES (Pinus caribaea)}

\section{Erratum}

In the initial publication of this article, we transposed the initials in author A. U. Chukwu's name. We regret this error, and have corrected the article. 


\section{On Comparison of Exponential and Hyperbolic Exponential Growth Models in Height/Diameter Increment of PINES (Pinus caribaea)}

\author{
Oyamakin S. $O$. \\ University of Ibadan \\ Ibadan, Nigeria
}

\author{
Chukwu A. U. \\ University of Ibadan \\ Ibdan, Nigeria
}

\author{
Bamiduro T. A. \\ Redeemer's University \\ Ogun State, Nigeria
}

A new tree growth model called the hyperbolic exponential nonlinear growth model is suggested. Its ability in model prediction was compared with the Malthus or exponential growth model an approach which mimicked the natural variability of heights/diameter increment with respect to age and therefore provides more realistic height/diameter predictions as demonstrated by the results of the Kolmogorov Smirnov test and ShapiroWilk test. The mean function of top height/Dbh over age using the two models under study predicted closely the observed values of top height/Dbh in the Hyperbolic exponential nonlinear growth models better than the ordinary exponential growth model without violating most of the assumptions about the error term.

Keywords: $\quad$ Model, height, Dbh, forest, Pinus caribaea, hyperbolic.

\section{Introduction}

The Caribbean Pine, Pinus caribaea, is a hard pine, native to Central America, Cuba, the Bahamas, and the Turks and Caicos Islands. It belongs to Australes Subsection in Pinus Subgenus. It inhabits tropical and subtropical coniferous forests, which include both lowland savannas and montane forests. Wildfire plays a major role limiting the range of this species, but it has been reported that this tree regenerates quickly and aggressively, replacing latifoliate trees. In zones not subject to periodic fires, the succession continues and a tropical forest thrives. It has been widely cultivated outside its natural range, and introduced populations can be found today in Jamaica, Colombia, South Africa or China. The species has three distinct varieties, one very distinct and treated as a

Oyamakin Oluwafemi Samuel is a Lecturer in the Deptartment of Statistics. Email at: fm_oyamakin@yahoo.com.Chukwu Angela Unna is in the Department of Statistics. Bamiduro Timothy Adebayo is in the Department of Mathematical Sciences. 


\section{EXPONENTIAL AND HYPERBOLIC EXPONENTIAL GROWTH MODELS}

separate species by some authors. These are Pinus caribaea var. caribaea, Pinus caribaea var. bahamensis (Bahamas Pine), and Pinus caribaea var. hondurensis (Honduras Pine).

Pines are a member of the gymnosperms, which literally means 'naked seed'. This is because the ovule (which develops into the seed) is not enclosed during fertilization within a fruit-like structure like it is in flowering plants. Gymnosperms are an ancient lineage of plants that were abundant during the era of the dinosaurs. Pines are wind 'pollinated' and do not have flowers. They bear their seeds in distinctive pinecone. Other gymnosperms in Belize include the cycads that are common in the savanna and mountain cypress (Podocarpus guatemalensis) a tree found particularly in upland forests.

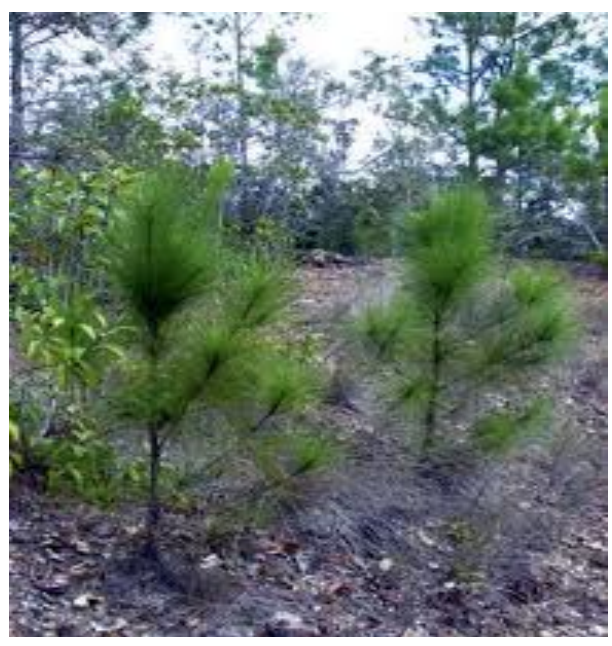

Figure 1. Growing Pines

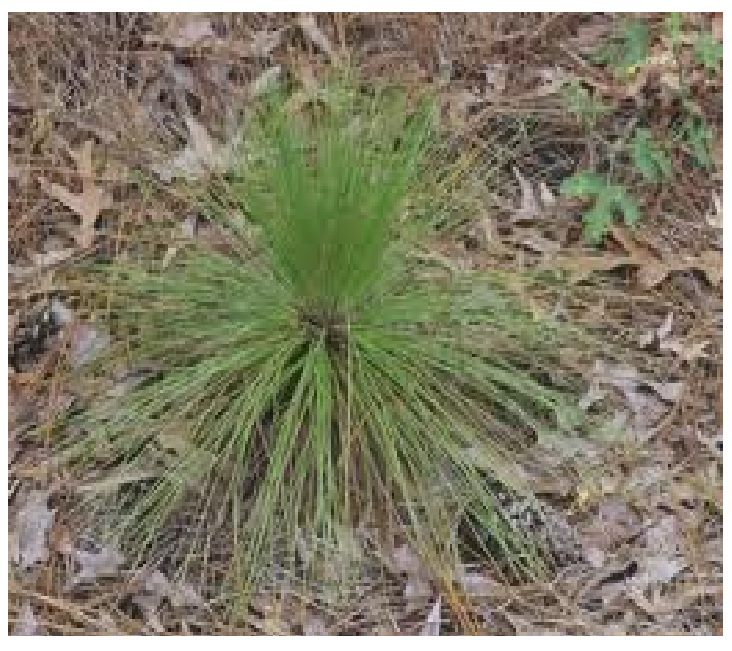

Figure 2. A young Pine

A mathematical description of a real world system is often referred to as a mathematical model. A system can be formally defined as a set of elements also called components. A set of trees in a forest stand, producers and consumers in an economic system are examples of components. The elements (components) have certain characteristics or attributes and these attributes have numerical or logical values. Among the elements, relationships exist and consequently the elements are interacting. The state of a system is determined by the numerical or logical values of the attributes of the system elements. Experimenting on the state of a system with a model over time is termed simulation (Kleijnen, 1987). Scientific forest management relies to a large measure on the predictions of the future 


\section{OYAMAKIN, CHUKWU \& BAMIDURO}

conditions of individual stands. This is achieved by predicting the increment from the current stand structure and updating the current values at each cycle of iteration using a growth model. The structural changes over time can be monitored under different cutting cycles and cutting intensities and optimal management policies can be arrived at based on the results of such simulation runs

Jayaraman and Bailey (1988) proposed a growth model useful for simulating the changes occurring in an uneven aged mixed species stand. The mean annual increment in basal area and number of trees is predicted from the current values of basal area, number of trees, site quality and species composition of the stand and the simulation proceeds by progressive updating of the values of predictor variables in annual cycles. Changes in site quality are carried forward through a linear difference equation. Volume estimates at each time point can be obtained by an appropriate height-diameter relation and a volume table function.

Kumar (1988) reviews the different supply and demand models available in forestry and suggests a new model for a small wood producing country. The model essentially consists of a supply equation, an export function, a home demand equation and ar: identity on the inventories. Functional forms for the equations will have to be determined by empirical verification. Parameters can be estimated if data are available on a lengthy time series basis after converting the model to its reduced form. The reduced form expresses each current exogenous variable as a function of exogenous and lagged endogenous variables. Deterministic simulation can then be undertaken by tracing the time path of endogenous variables by specifying initial values for exogenous and lagged endogenous variables. 

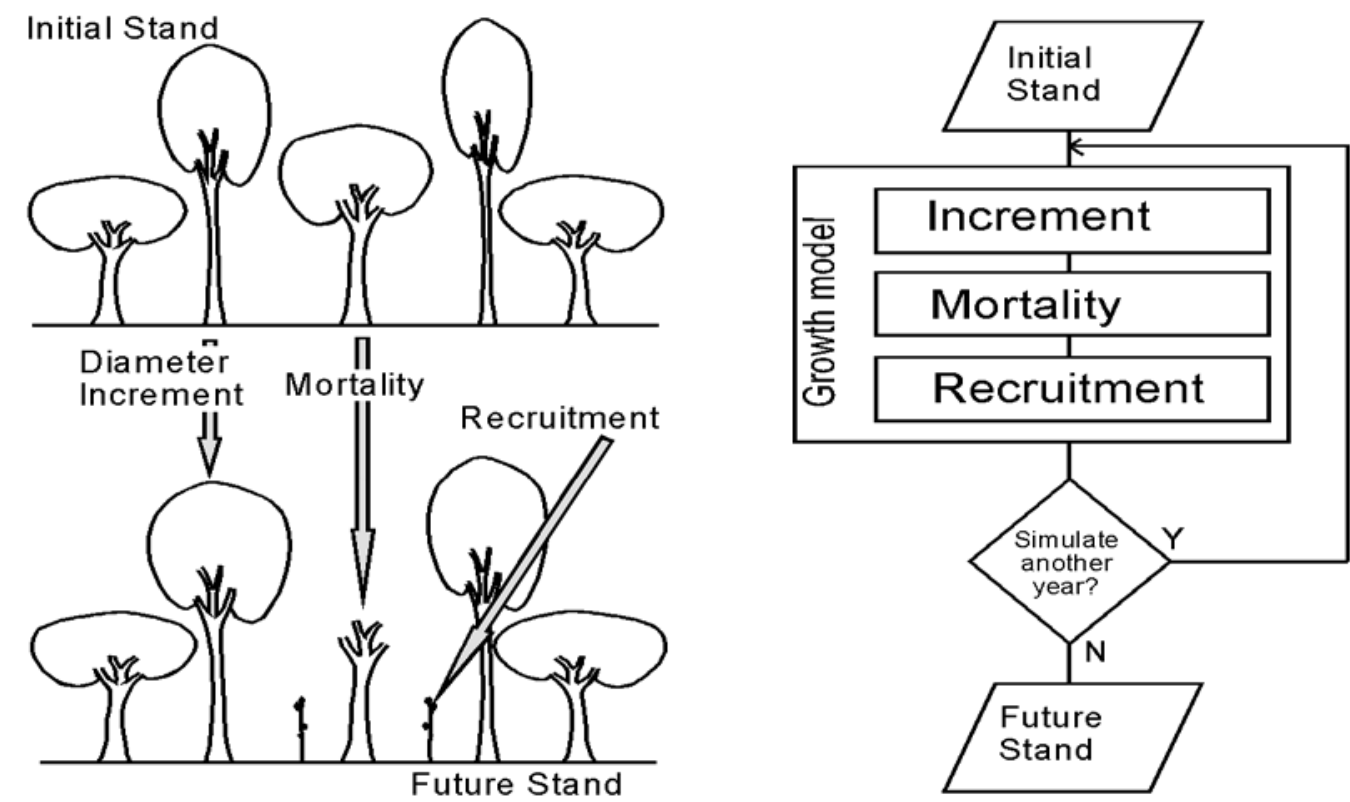

Figure 3. Components of forest growth and the analogous representation in a stand growth model.

Growth models assist forest researchers and managers in many ways. Some important uses include the ability to predict future yields and to explore silvicultural options. Models provide an efficient way to prepare resource forecasts, but a more important role may be their ability to explore management options and silvicultural alternatives. For example, foresters may wish to know the long-term effect on both the forest and on future harvests, of a particular silvicultural decision, such as changing the cutting limits for harvesting. With a growth model, they can examine the likely outcomes; both with the intended and alternative cutting limits and can make their decision objectively. The process of developing a growth model may also offer interesting new insights into stand dynamics. 


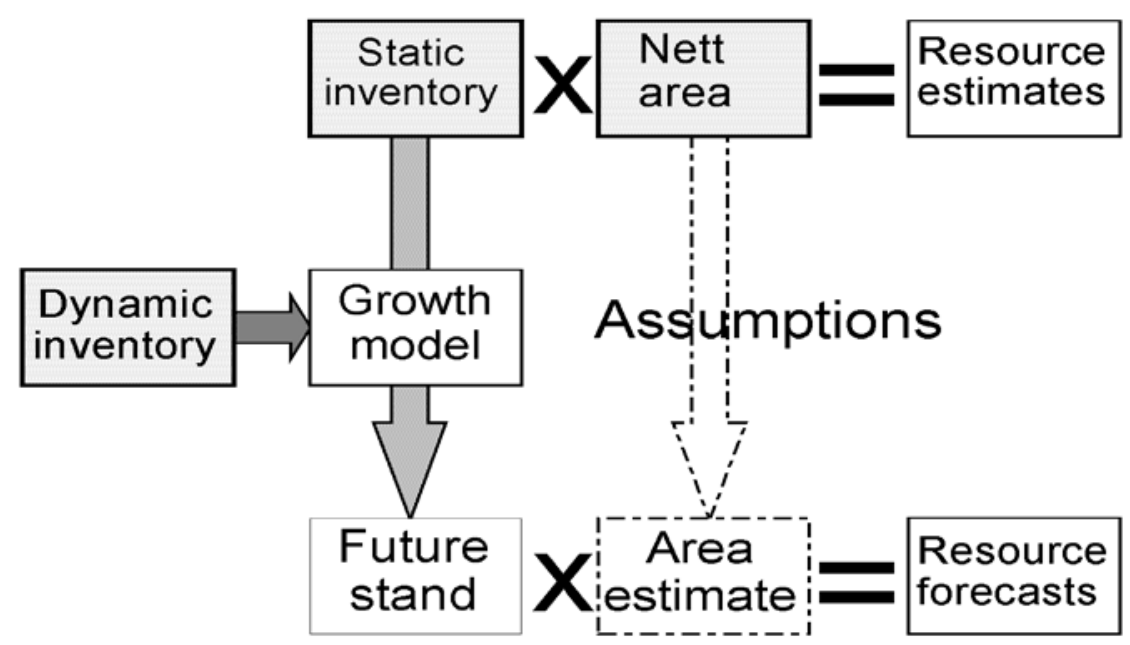

Figure 4. The role of growth models and complementary data in providing forest management information.

The total height $(\mathrm{Ht})$ of a tree is important for assessing tree volume (Walters et al., 1985; Walters and Hann, 1986) and stand productivity through site index (Hann and Scrivani, 1987), but accurate measurement of this variable is time consuming. As a result, foresters often choose to measure only a few trees' heights and estimate the remaining heights with height-diameter equations. Foresters can also use height-diameter equations to indirectly estimate height growth by applying the equations to a sequence of diameters that were either measured directly in a continuous inventory or predicted indirectly by a diametergrowth equation. The diameter-growth prediction approach can be valuable for modeling growth and yield of trees and stands as it's done in ORGANON (Hann et al., 1997). A number of studies of height-diameter relationships in northwestern Oregon, western Washington, and southwest British Columbia have already been published. Curtis (1967) investigated several equations for Douglas-fir that included tree diameter outside bark at breast height $(D B H)$ as an explanatory variable. Larsen and Hann (1987), and Wang and Hann (1988), using a variant of Curtis's (1967) recommended model, found that an equation which included tree diameter and site index was a better height predictor for 6 of 16 species in the mid-Willamette Valley. Krumland and Wensel (1988) included top height and quadratic mean diameter in their height-diameter equation.

Predicting total tree height based on observed diameter at breast height outside bark is routinely required in practical management and silvicultural 


\section{EXPONENTIAL AND HYPERBOLIC EXPONENTIAL GROWTH MODELS}

research work (Meyer, 1940). The estimation of tree volume, as well as the description of stands and their development over time, relies heavily on accurate height-diameter functions (Curtis, 1967). Many growth and yield models also require height and diameter as two basic input variables, with all or part of the tree height predicted from measured diameters (Burkhart et al., 1972; Curtis et al., 1981; Wykoff et al., 1982). In the cases where actual measurements of height growth are not available, height-diameter functions can also be used to indirectly predict height growth (Larsen and Hann 1987). Curtis (1967) summarized a large number of available height-diameter functions and used Furnival's index of fit to compare the performance of 13 linear functions fitted to second-growth Douglasfir (Pseudotsuga menziesii (Mirb.) Franco) data. Since then, many new heightdiameter functions have been developed. With the relative ease of fitting nonlinear functions and the nonlinear nature of the height-diameter relationships, nonlinear height-diameter functions have now been widely used in height predictions (Schreuder et al., 1979; Curtis et al., 1981; Wykoff et al., 1982; Wang and Hann 1988; Farr et al., 1989; Arabatzis and Burkhart, 1992).

Individual tree heights and diameters are essential measurements in forest inventories, and are used in estimating timber volume, site index and other important variables related to forest growth and yield, succession and carbon budget models (Peng, 2001). The time taken to measure tree heights takes longer than measuring the diameter at breast height. For this reason, often only the heights of a subset of trees of known diameter are measured, and accurate heightdiameter equations must be used to predict the heights of the remaining trees to reduce the cost involved in data acquisition. If stand conditions vary greatly within a forest, a height regression may be derived separately for each stand, or a generalized function, which includes stand variables to account for the variability, may be developed (Curtis, 1967; Zhang et al., 1997; Sharma and Zhang, 2004). Two trees within the same stand and that have the same diameter are not necessarily of the same height; therefore a deterministic model does not seem appropriate for mimicking the real natural variability in height (Parresol and Lloyd, 2004).

The objective of the present study was to evaluate the performance of a stochastic height-diameter approach in mimicking the observed natural variability in Gmelina Arborea heights recorded in 2011. 


\section{OYAMAKIN, CHUKWU \& BAMIDURO}

\section{Material and Methods}

A fundamental nonlinear least squares assumption is that the error term in all the height-diameter functions considered are independent and identically distributed with zero mean and constant variance. However, in many forestry situations there is a common pattern of increasing variation as values of the dependent variable increase. This is clearly evident from the scatterplots of height versus $D B H$ in Figure 2, where the values of the error are more likely to be small for small $D B H$ and large for large $D B H$. When the problem of unequal error variances occurs, weighted nonlinear least squares (WNLS) is applied, with the weights selected to be inversely proportional to the variance of the error terms.

We used data from Gmelina Arborea even-aged stands located in Federal College of Forestry, Ibadan. The stand conditions within the plantation were similar and thus we consider the data obtained as belonging to the stands.

\section{Method of Estimation}

Consider a nonlinear model

$$
H_{i}=f\left(D_{i}, \boldsymbol{B}\right)+\mathcal{E}_{i}
$$

$i=1,2, \ldots, n$, Where $H$ is the response variable, $D$ is the independent variable, $\boldsymbol{B}$ is the vector of the parameters $\beta_{j}$ to be estimated $\left(\beta_{1}, \dagger \beta_{2} \ldots \ldots, \beta_{p}\right), \mathcal{E}_{i}$ is a random error term , $p$ is the number of unknown parameters, $n$ is the number of observation. The estimator of $\beta_{j}$ 's are found by minimising the sum of squares residual $\left(S S_{R s s}\right)$ function

$$
S S_{R s s}=\sum_{i=1}^{n}\left[H_{i}-f\left(D_{i}, B\right)\right]^{2}
$$

Under the assumption that the $\mathcal{E}_{\boldsymbol{i}}$ are normal and independent with mean zero and common variable $\sigma^{2}$. Since $H_{i}$ and $D_{i}$ are fixed observations, the sum of squares residual is a function of $\boldsymbol{B}$, these normal equations take the form of 


$$
\sum_{i=1}^{n}\left\{H_{i}-f\left(D_{i}, \boldsymbol{B}\right)\right\}\left[\frac{\partial f\left(D_{i}, B\right)}{\partial \beta_{j}}\right]=0
$$

For $j=1,2, \ldots, p$. When the model is nonlinear in the parameters so are the normal equations consequently, for the nonlinear model, consider Table 2, it is impossible to obtain the closed solution of the least squares estimate of the parameter by solving the $p$ normal equations describe in Eq (3). Hence an iterative method must be employed to minimize the $s_{\text {Res }}$ (Draper and Smith 1981, Ratkowsky 1983).

The hyperbolic functions have similar names to the trigonometric functions, but they are defined in terms of the exponential function. The three main types of hyperbolic functions and the sketch of their graphs are given below.

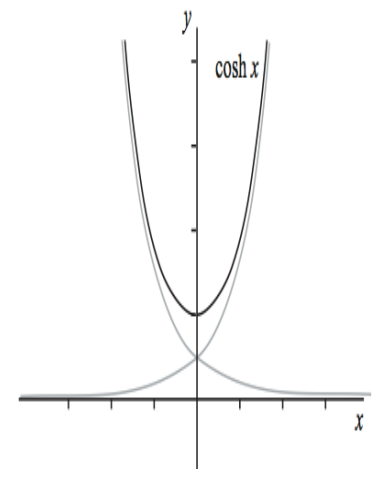

(a) Cosh Function

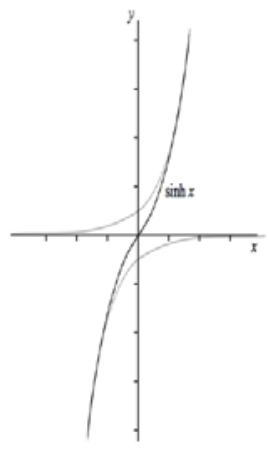

(b) Sinh function

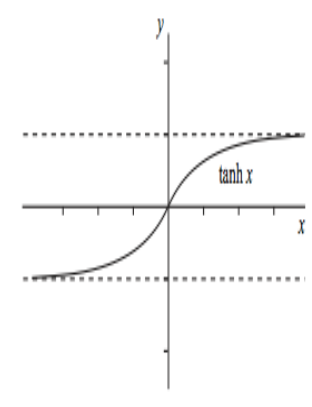

(c) Tanh Function

The function (b) above is pronounced as 'shine', or sometimes as 'sinch'. The function is defined by the formula

$$
\sinh x=\frac{e^{x}-e^{-x}}{2}
$$

Again, we can use our knowledge of the graphs of $e x$ and $e^{-x}$ to sketch the graph of $\sinh x$. First, let us calculate the value of $\sinh 0$. When $x=0, e^{x}=1$ and $e^{-x}=1$. So 


$$
\sinh x=\frac{e^{0}-e^{-0}}{2}=\frac{1-1}{2}=0
$$

Next, let us see what happens as $x$ gets large. We shall rewrite sinh $x$ as;

$$
\sinh x=\frac{e^{x}}{2}-\frac{e^{-x}}{2}
$$

To see how this behaves as $\mathrm{x}$ gets large, recall the graphs of the two exponential functions.

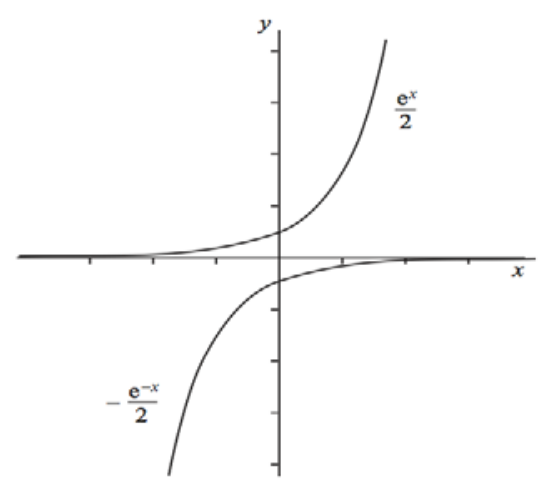

\section{Graph of exponential functions}

As $x$ gets larger, $e^{x}$ increases quickly, but $e^{-x}$ decreases quickly. So the second part of the difference $\frac{e^{x}}{2}-\frac{e^{-x}}{2}$ gets very small as $x$ gets large. Therefore, as $x$ gets larger, $\sinh x$ gets closer and closer to $\frac{e^{x}}{2}$. This is written as;

$$
\operatorname{Sinh} x \approx \frac{e^{x}}{2} \text { For large } x
$$




\section{EXPONENTIAL AND HYPERBOLIC EXPONENTIAL GROWTH MODELS}

But the graph of Sinh $x$ will always stay below the graph $\frac{e^{x}}{2}$. This is because, even though $-\frac{e^{-x}}{2}$ (the second part of the difference) gets very small, it is always less than zero. As $x$ gets larger and larger the difference between the two graphs gets smaller and smaller.

Next, suppose that $x$ is negative. As becomes more negative, $-e^{-x}$ becomes large and negative very quickly, but $e x$ decreases very quickly. So as $x$ becomes more negative, the first part of the difference $\frac{e^{x}}{2}-\frac{e^{-x}}{2}$ gets very small. So $\sinh x$ gets closer and closer to $-\frac{e^{-x}}{2}$. This is written as;

$\operatorname{Sinh} x \approx \frac{-e^{x}}{2}$ For large negative $x$

Now the graph of $\sinh x$ will always stay above the graph of $\frac{e^{-x}}{2}$ when $x$ is negative. This is because, even though $\frac{e^{x}}{2}$ (the first part of the difference) gets very small, it is always greater than zero. But as $x$ gets more and more negative the difference between the two graphs gets smaller and smaller.

We can now sketch the graph of $\sinh x$. Notice that $\sinh (-x)=-\sinh x$.

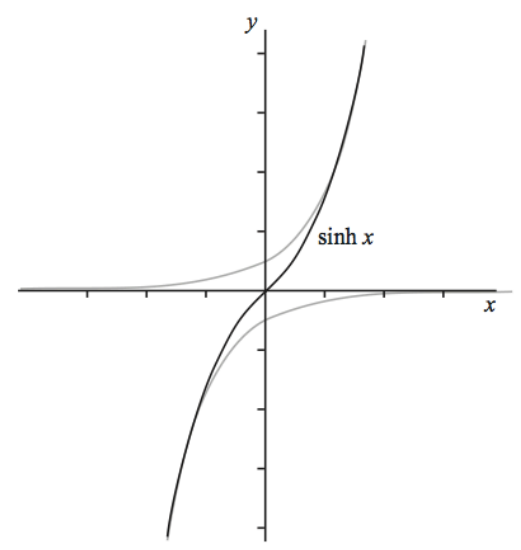

\section{Graph of $\sinh (x)$}




\section{OYAMAKIN, CHUKWU \& BAMIDURO}

Hence, the hyperbolic sine function and its inverse provide an alternative method for evaluating;

$$
\int \frac{1}{\sqrt{1+x^{2}}} d x
$$

If we make the substitution, then;

$$
\sqrt{1+x^{2}}=\sqrt{1+\sinh ^{2}(u)}=\sqrt{\cosh ^{2}(u)}=\cosh (u)
$$

Where the second equality follows from the identity $\cosh ^{2}(u)-\sinh ^{2}(u)=1$ and the last equality from the fact that $\cosh (u)>0$ for all $u$. Hence;

$$
\int \frac{1}{\sqrt{1+x^{2}}} d x=\int \frac{\cosh (u)}{\cosh (u)} d u=\int d u=u+c=\sinh ^{-1}(x)+c
$$

The following proposition is a consequence of the integral above i.e.

$$
\frac{d}{d x} \sinh ^{-1}(x)=\frac{1}{\sqrt{1+x^{2}}}
$$

Also, using the substitution $x=\tan (u),-\frac{\pi}{2}<u<\frac{\pi}{2}$, that

$$
\int \frac{1}{\sqrt{1+x^{2}}} d x=\log \left|x+\sqrt{1+x^{2}}\right|+c
$$

Since two anti-derivatives of a function can differ at most by a constant, there must exist a constant $k$ such that

$$
\sinh ^{-1}(x)=\log \left|x+\sqrt{1+x^{2}}\right|+k
$$

for all $x$. Evaluating both sides of this equality at $x=0$, we have 


$$
0=\sinh ^{-1}(0)=\log (1)+k=k
$$

Thus $k=0$ and

$$
\sinh ^{-1}(x)=\log \left|x+\sqrt{1+x^{2}}\right|_{\sqrt{ }}
$$

for all $x$. Since the hyperbolic sine function is defined in terms of the exponential function, we should not find it surprising that the inverse hyperbolic sine function may be expressed in terms of the natural logarithm function.

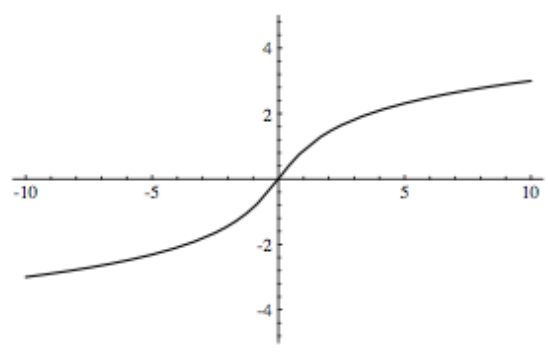

Graph of $\operatorname{arcsinh}(x)$

\section{Hyperboloastic Exponential Growth Model (HEGM)}

$$
\frac{\partial H}{\partial t}=H\left[r+\frac{\theta}{\sqrt{1+t^{2}}}\right]
$$

Separating the variables we have that;

$$
\frac{\partial H}{H}=\left[r+\frac{\theta}{\sqrt{1+t^{2}}}\right] d t
$$

Integrating both sides we have that;

$$
\ln H=r t+\theta \operatorname{arcsinh}(t)+C_{1}
$$


Hence,

$$
H=A e^{r t+\theta \operatorname{arcsinh}(t)}
$$

Therefore, we shall apply the two models below on Age-height and AgeDiameter of pines (pinus carean) growth;

(1) $\quad H=A e^{r t+\theta \operatorname{arcsinh}(t)}+\varepsilon$, and $D=A e^{r t+\theta \operatorname{arcsinh}(t)}+\varepsilon$

(2) $\quad H=A e^{r t}+\varepsilon$, and $D=A e^{r t}+\varepsilon$

\section{Result and Discussion}

Tables 1-4 below shows the estimated parameter for exponential and hyperbolic exponential growth model with their respective coefficient of determination $\left(R^{2}\right)$ for age-height/age-diameter models

Table 1. Height Parameter Estimates using Exponential growth model

\begin{tabular}{|c|c|c|c|c|}
\hline \multirow[b]{2}{*}{ Parameter } & \multirow[b]{2}{*}{ Estimate } & \multirow[b]{2}{*}{ Std. Error } & \multicolumn{2}{|c|}{ 95\% Confidence Interval } \\
\hline & & & Lower Bound & Upper Bound \\
\hline a & 9.33 & 0.559 & 8.138 & 10.522 \\
\hline b & 0.013 & 0.001 & 0.01 & 0.015 \\
\hline
\end{tabular}

$R$-Square $=90.9 \%$

Table 2. Height Parameter Estimates using Hyperbolic Exponential growth model

\begin{tabular}{ccccc}
\hline & & & \multicolumn{2}{c}{$95 \%$ Confidence Interval } \\
\cline { 3 - 5 } Parameter & Estimate & Std. Error & Lower Bound & Upper Bound \\
\hline $\mathrm{a}$ & 2.178 & .992 & .051 & 4.306 \\
$\mathrm{~b}$ & .001 & .003 & -.006 & .009 \\
$\mathrm{c}$ & .448 & .138 & .153 & .743 \\
\hline
\end{tabular}

$R$-Square $=95.2 \%$ 
EXPONENTIAL AND HYPERBOLIC EXPONENTIAL GROWTH MODELS

Table 3. Diameter Parameter Estimates using Exponential growth model

\begin{tabular}{ccccc}
\hline & & & \multicolumn{2}{c}{$95 \%$ Confidence Interval } \\
\cline { 4 - 5 } Parameter & Estimate & Std. Error & Lower Bound & Upper Bound \\
\hline $\mathrm{a}$ & 10.945 & .515 & 9.847 & 12.043 \\
$\mathrm{~b}$ & .013 & .001 & .011 & .015 \\
\hline
\end{tabular}

R-Square $=94.5 \%$

Table 4. Diameter Parameter Estimates using Hyperbolic Exponential growth model

\begin{tabular}{ccccc}
\hline & & & \multicolumn{2}{c}{$95 \%$ Confidence Interval } \\
\cline { 3 - 5 } Parameter & Estimate & Std. Error & Lower Bound & Upper Bound \\
\hline $\mathrm{a}$ & 2.503 & .680 & 1.044 & 3.963 \\
$\mathrm{~b}$ & .002 & .002 & -.003 & .006 \\
$\mathrm{c}$ & .452 & .082 & .276 & .628 \\
\hline
\end{tabular}

$R$-Square $=98.3 \%$

Also, the predicted and observed height and diameter were plotted to show the relationship and how best the models predicted the observed data on height and diameter of pines. This is also shown in the figure below:

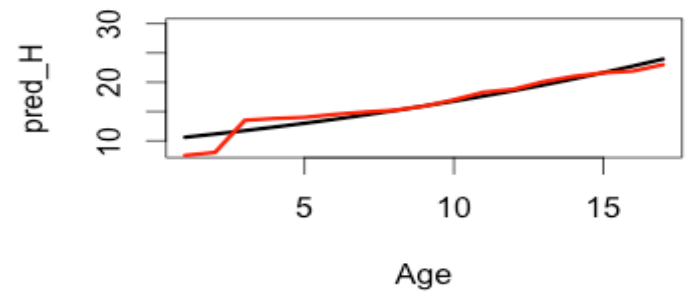

Figure 5. Observed Height against Predicted height (Exponetial growth model)

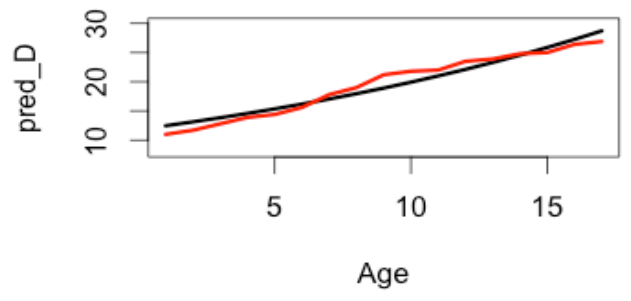

Figure 6. Observed Diameter against Predicted diameter (Exponetial growth model) 


\section{EXPONENTIAL AND HYPERBOLIC EXPONENTIAL GROWTH MODELS}

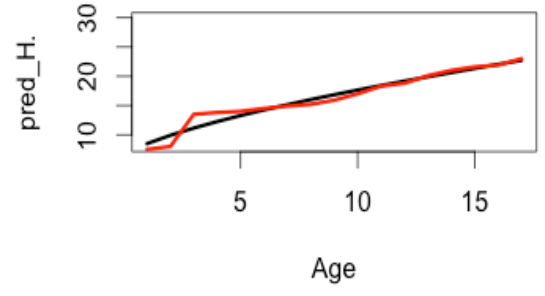

Figure 7. Observed Height against Predicted height

(Hyperbolic exponetial growth model)

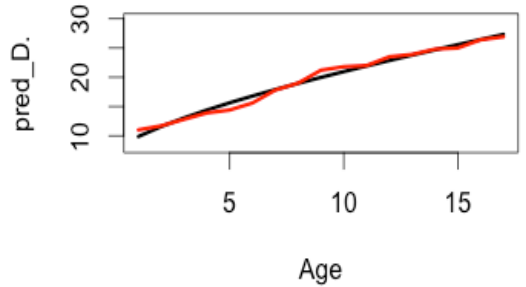

Figure 8. Observed Diameter against Predicted diameter (Hyperbolic exponetial growth model)

Table 5. ANOVA summary for Height Parameter Estimates using Exponential growth

\begin{tabular}{cccc}
\hline Source & Sum of Squares & $\boldsymbol{d f}$ & Mean Squares \\
\hline Regression & 4873.136 & 2 & 2436.568 \\
Residual & 29.424 & 15 & 1.962 \\
Uncorrected Total & 4902.560 & 17 & \\
Corrected Total & 323.678 & 16 & \\
\hline
\end{tabular}

Dependent variable: height

a. $R$ squared $=1$ - (Residual Sum of Squares) $/$ (Corrected Sum of Squares $)=.909$.

Table 6. ANOVA summary for Height Parameter Estimates using Hyperbolic Exponential growth model

\begin{tabular}{cccc}
\hline Source & Sum of Squares & $\boldsymbol{d f}$ & Mean Squares \\
\hline Regression & 4886.955 & 3 & 1628.985 \\
Residual & 15.605 & 14 & 1.115 \\
Uncorrected Total & 4902.560 & 17 & \\
Corrected Total & 323.678 & 16 & \\
\hline
\end{tabular}

Dependent variable: height

a. $R$ squared $=1$ - (Residual Sum of Squares) $/$ (Corrected Sum of Squares) $=.952$. 
EXPONENTIAL AND HYPERBOLIC EXPONENTIAL GROWTH MODELS

Table 7. ANOVA summary for Diameter Parameter Estimates using Exponential growth model

\begin{tabular}{cccc}
\hline Source & Sum of Squares & df & Mean Squares \\
\hline Regression & 6910.833 & 2 & 3455.417 \\
Residual & 25.417 & 15 & 1.694 \\
Uncorrected Total & 6936.250 & 17 & \\
Corrected Total & 464.198 & 16 & \\
\hline
\end{tabular}

Dependent variable: height

a. $R$ squared $=1$ - (Residual Sum of Squares) $/$ (Corrected Sum of Squares) $=.945$.

Table 8. ANOVA: Diameter Parameter Estimates using Hyperbolic Exponential growth model

\begin{tabular}{cccc}
\hline Source & Sum of Squares & $\boldsymbol{d f}$ & Mean Squares \\
\hline Regression & 6928.553 & 3 & 2309.518 \\
Residual & 7.697 & 14 & .550 \\
Uncorrected Total & 6936.250 & 17 & \\
Corrected Total & 464.198 & 16 & \\
\hline
\end{tabular}

Dependent variable: height

a. $R$ squared $=1$ - (Residual Sum of Squares) $/$ (Corrected Sum of Squares) $=.983$.

\section{Testing for Independence of Errors (Run test) and Normality of Error (Shapiro-Wilk test)}

Two assumptions made in the models are:

Errors are independent

Errors are normally distributed.

These assumptions were verified by examining the residuals. If the fitted models are correct, residuals should exhibit tendencies that tend to confirm or at least should not exhibit a denial of the assumptions.

Hence, we tested the following hypotheses stated below; 


\section{OYAMAKIN, CHUKWU \& BAMIDURO}

$H_{0}$ : Errors are independent

(Using Runs Test)

$H_{1}$ : Errors are not independent

And

$H_{0}$ : Errors are normally distributed

$H_{1}$ : Errors are not normally distributed

(Using Shapiro-Wilk test)

Let $m$ be the number of pluses and $n$ be the number of minuses in the series of residuals. The test is based on the number of runs(r), where a run is defined as a sequence of symbols of one kind separated by symbols of another kind. A good large sample approximation to the sampling distribution of the number of runs is the normal distribution with mean;

$$
\text { Mean }=\frac{2 m n}{m+n}+1
$$

and,

$$
\operatorname{Variance}\left(\sigma^{2}\right)=\frac{2 m n(2 m n-m-n)}{(m+n)^{2}(m+n-1)}
$$

Therefore, for large samples like ours the required test statistic is;

$$
Z=\frac{(r+h-\mu)}{\sigma} \sim N(0,1)
$$

where,

$$
h=\left\{\begin{array}{l}
0.5, \text { if } r<\mu \\
-0.5, r>\mu
\end{array}\right.
$$

Also, the required test statistic for the test of normality (Shapiro-Wilk test) is given by; 


$$
W=\frac{S^{2}}{b}
$$

Where;

$$
S^{2}=\sum a(k)\left\{x_{n+1-k}-x_{(k)}\right\}
$$

and,

$$
b=\sum\left(x_{i}-\bar{x}\right)^{2}
$$

In the above, the parameter $k$ takes the values; $x_{(k)}$ is the $k^{\text {th }}$ order statistic of the set of residuals and the values of coefficient $a(k)$ for different values of $n$ and $k$ are given in the Shapiro-Wilk table (1965). $H_{0}$ is rejected at level $\alpha$ i.e. $\mathrm{W}$ is less than the tabulated value.

Table 9. Result of the test of independence of Residuals using Run Test

\begin{tabular}{ccccc}
\hline Residual & Test Value & No. of Runs & $\boldsymbol{Z}$ & Asymp. Sig.(2 tailed) \\
\hline Exp. Height & -0.2000 & 5 & -1.802 & $0.072^{\star}$ \\
Exp. Diameter & -0.0318 & 3 & -3.002 & $0.003^{\star \star \star}$ \\
HExp. Height & -0.0047 & 6 & -1.494 & $0.135^{\text {ns }}$ \\
HExp. Diameter & 0.0035 & 4 & -2.499 & $0.012^{\star \star}$ \\
\hline
\end{tabular}

* Significant at $10 \%,{ }^{* \star}$ significant at $5 \%,{ }^{* \star}$ significant at $99 \%$ and ${ }^{\text {ns }}$ not significant

Table 10. Result of the test of normality of Residuals using K-S \& S-W Tests

\begin{tabular}{ccccc}
\hline \multirow{2}{*}{ Residual } & \multicolumn{2}{c}{ Kolmogorov-Sminov } & \multicolumn{2}{c}{ Shapiro-Wilk } \\
\cline { 2 - 5 } & Statistic & Asmp. Sig. & Statistic & Asmp. Sig. \\
\hline Exp. Height & 0.262 & $\mathbf{0 . 0 0 3 ^ { * \star * }}$ & 0.842 & $\mathbf{0 . 0 0 8 ^ { \star \star * }}$ \\
Exp. Diameter & 0.198 & $\mathbf{0 . 0 7 7 ^ { * }}$ & 0.933 & $\mathbf{0 . 2 4 4 ^ { n s }}$ \\
H Exp. Height & 0.172 & $\mathbf{0 . 1 9 3}^{\text {ns }}$ & 0.954 & $\mathbf{0 . 5 1 9}^{\text {ns }}$ \\
H Exp. Diameter & 0.192 & $\mathbf{0 . 0 9 5}^{\text {ns }}$ & 0.953 & $\mathbf{0 . 5 0 0}^{\text {ns }}$ \\
\hline
\end{tabular}

* Significant at $10 \%,{ }^{* *}$ significant at $5 \%,{ }^{\star \star *}$ significant at $99 \%$ and ${ }^{\text {ns }}$ not significant

\section{Conclusion}

The mean function of top height and Dbh over age using the Hyperbolic Exponential growth model predicted closely the observed values of top height and 


\section{OYAMAKIN, CHUKWU \& BAMIDURO}

Diameter of Pines. However, large correlations of the estimated parameters do not necessary mean that the original model is inappropriate for the physical situation under study. For example, in a linear model, when a particular $\beta$ (a coefficient) does not appear to be different from zero, it does not always imply that the corresponding $x$ (independent variable) is ineffective; it may be that, in a particular set of data under study, $x$ does not change enough for its effect to be discernible. In general, efficient parameter estimation can best be achieved through a good understanding of the meaning of the parameters, the mathematics of the model, including the partial derivatives, and the system being modeled.

\section{References}

Arabatzis, A. A., \& Burkhart, H. E. (1992). An evaluation of sampling methods and model forms for estimating height-diameter relationships in a loblolly pine plantation. For. Sci, 38, 192-198.

Brisbin, I. L. (1989). Growth curve analyses and their applications to the conservation and captive management of crocodilians. Proceedings of the Ninth Working Meeting of the Crocodile Specialist Group. Gland, Switzerland: SSCHUSN.

Burkhart, H. E., Parker, R. C., Strub, M. R., \& Oderwald R. G. (1972). Yield of old-field loblolly pine plantations. Blacksburg, VA: School of Forestry and Wildlife Resources, Virginia Polytechnic Institute and State University. PublFWS-3-72.

Bursac, Z, Tabatabai, M., \& Williams, D. K. (2007). Nonlinear Hyperbolastic Growth Models and Application in Craniofacial and Stem Cell Growth. ASA Biometrics Section (including ENAR and WNAR) 190-197.

Castro, M. A., Klamt, F., Grieneisen, V., et al. (2003). Gompertzian growth pattern correlated with phenotypic organization of colon carcinoma, malignant glioma and non-small cell lung carcinoma cell lines. Cell Prolif, 36(2), 65-73.

Chignola, R., Schenetti, A., Chiesa, E., et al. (1999). Oscillating growth patterns of multicellular tumor spheroids. Cell Prolif, 32, 39-48.

Curtis, R. O. (1967). Height-diameter and height-diameter-age equations for second-growth Douglas-fir. Forest science 13, 365 - 375.

Curtis, R. O., Clendenen, G. W., \& DeMars, D. J. (1981). A new stand simulator for coast Douglas-fir: DFSIM Users guide. USDA For. Serv. Gen. Tech. Rep. PNW - 128. 


\section{EXPONENTIAL AND HYPERBOLIC EXPONENTIAL GROWTH MODELS}

Deisboeck, T. S., Berens, M. E., Kansal, A. R., et al. (2001). Pattern of selforganization in tumour systems: complex growth dynamics in a novel brain tumour spheroid model. Cell Prolif, 34, 115-134.

Draper, N. R. \& Smith, H. (1981). Applied Regression Analysis. New York: John Wiley and Sons.

Farr, W. A., DeMas, D. J., \& Dealy, J. E. (1989). Height and crown width related to diameter for open-grown western hemlock and sitka spruce. Can. J. For. Res. 19, 1203 - 1207

Fekedulegn, D. (1996). Theoretical nonlinear mathematical models in forest growth and yield modeling (Thesis). Dept. of Crop Science, Horticulture and Forestry, University College Dublin, Ireland.

Foong, F. S. (1991). Potential evapotranspiration, potential yield and leaching losses of oil palm. Pro. 1991 PORIM Interl. Palm Oil Cong. (Agric.), $105-119$.

Foong, F. S. (1999). Impact of moisture on potential evapotranspiration, growth and yield of palm oil. Pro. 1999 PORIM Inter1.1 Palm oil Cong. (Agric), $265-287$

Gompertz, B. (1825). On the nature of the function expressive of the law of human mortality, and on a new mode of determining the value of life contingencies. Phil Trans of the Royal Soc, 182, 513-585.

Hann, D. W., Hester, A. S., \& Olsen, C. L. (1997). Organon Users manual edition 6.0. Department of Forest Resources, Oregon State University, Corvallis.

Hann, D. W., \& Scrivani, J. (1987). Dominant height-growth and site-index equations for Douglas-fir and ponderosa pine in southwest Oregon. Research Bulletin 59, Department of Forest Resources, Oregon State University, Corvallis

Ismail, Z., Khamis, A., \& Jaafar, M. Y. (2003). Fitting nonlinear Gompertz curve to tobacco growth data. Pak. J. Agro., 2, 223 - 236.

Jaafar, M. Y. (1999). Pensuaian model taklinear Gompertz terhadap pertumbesaran pokok koko. Matematika, 15, 1 - 20.

Jayaraman, K., \& Bailey, R. L. (1988) Modelling mixed species stands with Scheffe's canonical polynomials. In Ek, A.R., et al. (Ed.) Forest Growth Modelling and Prediction. Proceedings of the IUFRO Conference, Minnesota, 2327 August 1987, pp. 201-208. (KFRI Scientific Paper No. 515)

Kansal, A. R., Torquato, S., Harsh, G.R., et al. (2000). Simulated brain tumor growth dynamics using a three dimensional cellular automaton. $J$ Theor Biol, 203, 367-82. 


\section{OYAMAKIN, CHUKWU \& BAMIDURO}

Khamis, A., \& Ismail, Z. (2004). Comparative study on nonlinear growth curve to tobacco leaf growth data. J. Agro., 3, 147 - 153.

Kingland, S. (1982). The refractory model: The logistic curve and history of population ecology. Quart Rev Biol, 57, 29-51.

Kleijnen, J. P. C. (1987). Simulation with too many factors: review of random and group-screening designs. European Journal of Operational Research 31(1), 31-36.

Kramer, P. J., \& Kozlowski, T. T. (1979). Physiology of woody plants. New York: Academic Press.

Kumar, M. (1988). Reed Bamboo (Ochlandra) in Kerala: Distribution and management. In Rao, I.V.R., et al. (Ed.). Bamboos: Current Research. Proceedings of the International Bamboo Workshop, Cochin, 14-18 November 1988, pp. 39-43. (KFRI Scientific Paper No. 34)

Kumar, M., \& Manilal, K.S. (1988). Floral anatomy of Apostasia odorata and the taxonomic status of Apostasioids (Orchidaceae). Phytomorphology, 38(2/3), 159-162. (KFRI Scientific Paper No. 35)

Krumland, B. E., \& Wensel, L. C. (1988). A generalized height-diameter equation for coastal California species. Western Journal of Applied Forestry, 3, $113-115$

Larsen, D. R. \& Hann, D. W. (1987). Height-Diameter equations for seventeen tree species in southwest Oregon. Research paper 49, Forest Research laboratory, Oregon State University, Corvallis.

Maraquardt, D. W. (1963). An algorithm for least squares estimation of nonlinear parameters. Journal of the society for Industrial and Applied Mathematics, 11, 431 - 441.

Martin, G. L., \& Martin, A. R. (1984). A comparison of competition measures and growth models for predicting plantation red wine diameter and height growth. Forest Science, 30, 731-743.

Marusic, M., Bajzer, Z., Freyer, J. P., et al. (1994). Analysis of growth of multicellular tumor spheroids by mathematical models. Cell Prolif, 27, 73-94.

Marusic, M., Bajzer, Z., Vuk-Pavlovic, S., et al. (1994). Tumor growth in vivo and as multicellular spheroids compared by mathematical models. Bull Math Biol, 56, 617-31.

Methley, J. (1996). Bowmont sample plot data-end user licensed for data release. Forestry Commission Research Division, 12 June 1996, England. 


\section{EXPONENTIAL AND HYPERBOLIC EXPONENTIAL GROWTH MODELS}

Meyer, H. A. (1940). A mathematical expression for height curves. Journal of Forestry 38, 415 - 420.

Morgan, P. H., Mercer, L. P., \& Flodin, N. W. (1975). General model for nutritional response of higher organisms. Proc. Nat. Acad. Sci. USA, 72, 4327 4331

Myers, R. H. (1996). Classical and modern regression with applications. Boston, MA: Duxbury Press.

Nelder, J. A. (1961). The fitting of a generalization of the logistic curve. Biometrics, 17, 89-110.

Olea, N., Villalobos, M., Nunez, M. I., et al. (1994). Evaluation of the growth rate of MCF-7 breast cancer multicellular spheroids using three mathematical models. Cell Prolif, 27, 213-23.

Oliver, F. R. (1964). Methods of estimating the logistic function. Applied statistics, 13, 57-66.

Parresol, B. R., \& Lloyd, F. T. (2004). The stochastic tree modelling approach used to derive tree lists for the GIS/CISC identified stands at the Savannah River Site, Internal Report, USDA For. Serv. Southern Research Station, Asheville, NC.

Paul, J. R. (1971). History of Poliomyelitis. London: Yale University Press.

Peng, M. (2001). The resource-based view and international business. Journal of Management, 26(3), 513 -563.

Philip, M. S. (1994). Measuring trees and forests. 2nd Edition. Wallingford, UK: CAB International.

Phillips, B. F., \& Campbell, N. A. (1968). A new method of fitting the von Bertalanffy growth curve using data on the whelk. Dicathais Growth 32, 317-329.

Ratkowskay, D. A. (1983). Nonlinear Regression modeling. New York: Marcel Dekker.

Richards, F. J. (1959). A flexible growth functions for empirical use. Journal of Experimental Botany, 10, 290-300.

Ricklef, R. E., \& Scheuerlein, A. (2002). Biological implications of the Weibull and Gompertz models of aging. J Gerotol A Biol Sci Med Sci, 57(2), B69-B76.

SAS Institute Inc. (1985). SAS/STAT User's Guide, version 6, 4th edition. Vol. 1. Cary, NC: SAS Institute Inc.

SAS Institute Inc. (1992). SAS/STAT: User's Guide, Release 6.03 edition. Cary, NC: SAS Institute Inc. 


\section{OYAMAKIN, CHUKWU \& BAMIDURO}

Schnute, J. (1981). A versatile growth model with statistically stable parameters. Can. J. Fish. Aquat. Sci. 38, 1128.

Schreuder, H. T., Hafley, W. L., \& Bennett, F. A. (1979). Yield prediction for unthinned natural slash pine stands. For. Sci 25, 25 - 30.

Seber, G. A. F., \& Wild, C. J. (1989). Nonlinear Regression. New York: John Wiley and Sons.

Sharma, M., \& Zhang, S. Y. (2004). Height-Diameter models using stand characteristics for pinus banksiana and picea mariana. Scandinavian Journal of Forest Research, 19, 442-451.

Spratt, J. A., von Fournier, D., Spratt, J. S., et al. (1993). Decelerating growth and human breast cancer. Cancer, 71, 2013-9.

Tabatabai, M., Williams, D. K., \& Bursac, Z. (2005). Hyperbolastic growth models: Theory and application. Theor Biol Med Model, 2(14), 1-13.

Tsoularis, A., \& Wallace, J. (2002). Analysis of logistic growth models. Math. Biosci., 179, 21 - 55.

Vanclay, J. K. (1994). Modeling forest growth and yield. Wallingford, UK: CAB International.

Verhulst, P. F. (1838). A note on population growth. Correspondence Mathematiques et Physiques, 10, 113-121.

Von Bertalanffy, L. (1957). Quantitative laws in metabolism and growth. Quantitative Rev. Biology 32, 218-231.

Walters, D. K., Hann, D. W., \& Clyde, M. A. (1985). Equations and tables predicting gross total stem volume in cubic feet for six major conifers of southwest Oregon. Research Bulletin 50, Forest Resources, Oregon State University, Corvallis.

Wang, C. H., \& Hann, D. W. (1988). Height-Diameter equations for sixteen tree species in the central western Willamette valley of Oregon, Research paper 51, Forest Research Laboratory, Oregon State University, Corvallis.

Walters, D. K., \& Hann, D. W. (1986). Predicting merchantable volume in cubic feet to a variable top and in scribner board feet to a 6-inch top for six major conifers of southwest Oregon, Research Bulletin 52, Forest Resources, Oregon State University, Corvallis.

Weibull, W. (1951). A statistical distribution function of wide applicability. J of Appl Mech, 18, 293-297.

West, G. B., Brown, J. H., \& Enquist, B. J. (2001). A general model for antogenetic growth. Nature, 413, 628-631. 


\section{EXPONENTIAL AND HYPERBOLIC EXPONENTIAL GROWTH MODELS}

West, G. B., Brown, J. H.,, \& Enquist, B. J. (2004). Growth models based on first principles of Phenomenology? Funct Ecol, 18, 188-196.

Wykoff, W. R., Crookston, N. L. \& Stage, A. R. (1982). User's guide to the stand prognosis model. General Technical Report INT-133, USDA Forest Service, Inter-Mountain Forest and Range Experiment Station, Ogden UT.

Yin, X., Goudriaan, J., Latinga, E.A., et al. (2003). A flexible sigmoid function of determinate growth. Ann Bot (Lond), 91, 361-371.

Yuancai, L., Marques, C. P., \& Macedo, F. W. (1997). Comparison of Schnute's and Bertalanffy-Richards' growth function. Forest Eco. Mgmt., 96, 283 $-288$.

Zeide, B. (1993). Analysis of growth equations. Forest Sci, 39, 594-616.

Zhang, L. (1997). Cross-validation of non-linear growth functions for modeling tree height-diameter relationships. Annals of Botany, 79, 251-257.

Zhu, Q., Cao, X., \& Luo, Y. (1988). Growth analysis on the process of grain filling in rice. Acta Agronomica Sinica, 18, 182-193. 